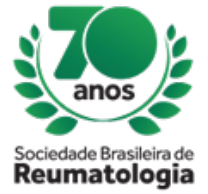

\title{
ANTIPHOSPHOLIPID ANTIBODY SYNDROME (APS) EXACERBATED IN THE POSTPARTUM PERIOD
}

Elisa Fernandes de Melo (Universidade de Taubaté, Taubaté, SP, Brasil), Vinicius Verlangieri Soubihe (Universidade de Taubaté, Taubaté, SP, Brasil), Raylane Shellyda de Almeida Anate (Universidade de Taubaté, Taubaté, SP, Brasil), Natália Engler Ravasio (Universidade de Taubaté, Taubaté, SP, Brasil), Laís Helena Bittencourt Ribeiro Soubhia (Universidade de Taubaté, Taubaté, SP, Brasil), Drielle Rezende

Pavanitto (Universidade de Taubaté, Taubaté, SP, Brasil), Tainara Mariana Ferreira Leismann

(Universidade de Taubaté, Taubaté, SP, Brasil), Felipe José dos Santos Pereira (Universidade de Taubaté, Taubaté, SP, Brasil), Pedro Luiz Homem de Mello (Universidade de Taubaté, Taubaté, SP, Brasil), Daniel Renato Gonçalves Duarte (Universidade de Taubaté, Taubaté, SP, Brasil), Glenda Alves Pereira de Oliveira (Universidade de Taubaté, Taubaté, SP, Brasil)

\section{BACKGROUND}

APS is an autoimmune disorder in which recurrent thrombotic events (arterial or venous) and obstetric complications occur in the presence of antiphospholipid antibodies. To confirm the APS are required 2 positive antiphospholipid antibodies testing in a 12 week interval. It may be triggered by some events such as infections, surgeries, pregnancy and post-partum phase.

\section{CASE REPORT}

A 33-year-old female patient sought the department of Obstetrics and Gynecology in labor and due to cephalopelvic disproportion/chorioamnionitis she had underwent a cesarean section, without complications. Previous report of still birth near the fifth month of gestation. In the post-partum, she presented with swelling and peripheral cyanosis in her right hand. Evolved unfavorably and a Doppler was performed showing a diffuse swelling of the soft tissue causing a collapse of the venous system and compartment syndrome. There wasn't sign of thrombosis in the scan but during the fasciotomy multiple local arterial and venous thrombosis were evidenced (figure 1). Laboratory tests revealed thrombocytopenia, false positive VDRL (1:2 and negative FTA-ABS), 1:80 fine nuclear dotted ANA, positive LAC, anticardiolipin IgM positive and ESR of 60 . Gathering the pregnancy loss, thrombocytopenia, false positive VDRL, positive antibodies, positive ANA e elevated ESR it is possible to confirm the diagnosis of APS. Treatment began with Enoxaparin anticoagulation followed by Warfarin, Hydroxychloroquine $400 \mathrm{mg} /$ day which improvement the clinical condition and provided a good outcome.

\section{CONCLUSION}

APS is an autoimmune disease characterized by the association of clinical manifestations such as thrombosis and/or gestational loss and the presence of antiphospholipid antibodies. It can be exacerbated during pregnancy and postpartum periods, and attention should be paid to these patients. Treatment is based on anticoagulation of these patients and control of triggering factors. 